\title{
The quality of teachers in making mathematical cognitive test instruments
}

\author{
Iva Sarifah ${ }^{1}$, Yetty Supriyati ${ }^{2}$, Wardani Rahayu ${ }^{3}$ \\ \{ivasarifah@unj.ac.id ${ }^{1}$, yetti.supriyati@unj.ac.id ${ }^{2}$, wardani.rahayu@unj.ac.id ${ }^{3}$ \} \\ Universitas Negeri Jakarta, Indonesia
}

\begin{abstract}
This study aims to analyze the effect of the self-efficacy beliefs and knowledge in constructing tests on the quality of teachers in making mathematical cognitive test instruments. Data was acquired from 100 elementary school teachers. The analysis of this study using statistical Confirmatory Factor Analysis techniques was then calculated by The Estimate of Structural Equation Models (SEM). It was found that the role of self-efficacy beliefs and constructive knowledge had a significant impact on the quality of mathematical cognitive test instruments made by elementary school teachers.
\end{abstract}

Keywords: Elementary School, Mathematical Cognitive, Structural Equation Models

\section{Introduction}

Teachers as an important component in education must have pedagogical, professional, personal and social competence. One of the competencies that need to be continuously improved is competence in carrying out learning assessments. This is one of the professional competencies that must be possessed by the teacher in carrying out his duties as an educator. To carry out the test, the teacher must use instruments. One of them is the cognitive test instrument made by the teacher.

Given that cognitive test instruments are an important element in carrying out the assessment of learning, as a measuring instrument, it must meet the requirements for the preparation of cognitive test instruments. Thus, the cognitive test instruments made by the teacher must meet good test requirements. The importance of good instrument requirements on teacher-made test instruments, in accordance with the results of research conducted by Dada and Morayo, is that they are not only a value-gathering tool but a proof-catching tool that must be carefully designed to ensure high validity and reliability. It is recommended that language teachers should be encouraged to continue to plan, build and carry out their tests well. [1]

To obtain the quality of the test, several factors that influence it must be considered. This is in accordance with what has been studied to determine the factors that influence the validity and reliability of tests made by teachers in Kenya. The findings of this study reveal that teacher experience, training in construction and test analysis, education level, use of Bloom's 
taxonomy, moderation of tests and length of test have an effect on the validity and reliability of teacher-made tests. Experienced teachers who had previous training in testing and therefore applied a number of these factors in their test construction tended to design tests with higher validity and reliability than their counterparts without training. This study recommends that teacher training in construction and test analysis need to be improved to enhance test validity and reliability.[2]

Given that the quality of cognitive test instruments or the level of validity and reliability of teacher-made cognitive test instruments has not guaranteed objectivity, the teacher must conduct validity and reliability analysis. One of these instruments made by teachers that need to be analyzed is a mathematics test. To be able to produce a mathematical test instrument made by qualified teachers, the teacher must have confidence in the abilities he has. This is a self-efficacy belief that the teacher has, which makes him responsible for making these instruments. This confidence will certainly encourage teachers to seriously produce test instruments that meet the standards. According to the results of research conducted by BrayClark and Bates, the framework in the development of teacher professionalism must include the self efficacy belief as a training design that aims to improve teacher competence.[3]

Such teachers must also possess knowledge of constructing tests, which is something that is required in designing test items in accordance with the rules for preparing test instruments. If the test instrument that is made does not pay attention to the rules in its preparation, it will not enable the achievement of the objectives of the assessment. This is because it does not meet the criteria that the test instruments made must be correct, accurate, reliable, objective, and accountable. Thus, knowledge of constructing test instruments has an important role in compiling cognitive test instruments so that they can measure students' success in learning. The results of other studies were stated by Rufina S. Hamafyelto, Tukur, and Stephen S. Hamafyelto that there is a significant relationship between competence in constructing exam questions with the validity of the test content made by the teacher.[4]

A study related to test quality but different from what the researchers investigated was the one conducted by Tshabalala, et al. The results of this study indicate that teacher-made tests are given to students in schools and there is tremendous acceptance by respondents that these tests help improve student academic performance. It was also found that most teachers were not knowledgeable about standard procedures for building, marking and assessing tests. The study recommends that there is a need for schools to carry out staff development programs to equip teachers with the skills to make teacher-made tests.[5]The identified research related to the influence of knowledge of constructing the test is the study of Lei Mee Ing, et al. The results of this study found that knowledge of designing grid test instruments had an impact on teacher-made tests.[6]Another study was conducted by Simsek and the results found that there were similarities in making a test between teachers who had knowledge of measurement and evaluation with trainers.[7] 
Additionally, research done by Lunenburg found that self efficacy (beliefs about a person's ability to complete a particular task) affects the tasks that employees choose to learn and the goals they set for themselves. Self-efficacy also affects the level of effort and perseverance of employees when learning difficult tasks. [8]

\section{Method}

The sample of this study was 100 elementary school teachers in 5 districts of DKI Jakarta province. The quality of teachers in making mathematical cognitive test instruments and test performance data was conducted by three rater evaluation. This assessment conducted by 3 rater people was carried out on construct validity and instrument reliability. Construct validity was tested using Gregory's formula while the reliability of teacher-made instruments was calculated using the hoyt formula; The self efficacy belief data was obtained by questionnaire with a Likert scale and knowledge in constructing test data was acquired by multiple choice test. The instrument reliability coefficient of self efficacy belief amounted to 0.9392 which was calculated using the Cronbach Alpha formula and the instrument reliability coefficient of knowledge in constructing tests amounted to 0.8743 which was calculated using the KR-20 formula. The Confirmatory Factor Analysis Techniques method used is calculated by The Estimate of Structural Equation Models (SEM) with Lisrel Programe. (See at https://osf.io/jvsmp/ )

\section{Result and Discussion}

The structural equation model tested the hypothesis that self efficacy beliefs and knowledge in constructing tests affect the quality of teachers in making mathematical cognitive test instruments. The path coefficients of the modified structural model for the total group are given in figure 1 and 2.
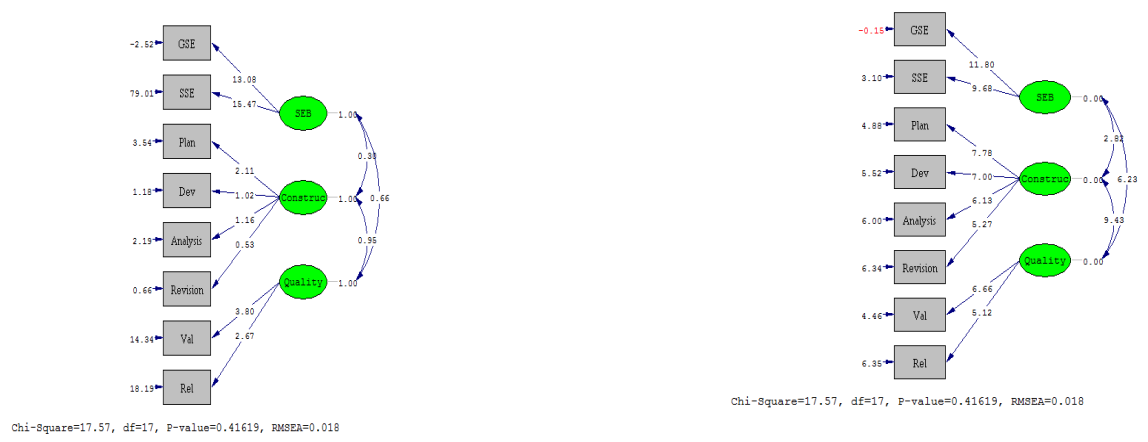
Fig 1. The Estimate of the Hypothesis
Fig. 2. T-Value of the Hypothesis

The results indicated that the overall model fits the data reasonably well. All the parameter estimates were significant $(\mathrm{P}<0.05)$ in terms of obtained values. The most important indices were utilized as evidence of fit. Self-efficacy belief has a direct effect $(\beta=$ 0.30 ) on the quality of teachers in making mathematical cognitive test instruments and knowledge in constructing test has a direct effect $(B=0.95)$ on the quality of teachers in making these instruments.

In this measurement model, it can be stated that the quality of teachers in making mathematical cognitive test instruments is supported by self-efficacy beliefs and knowledge in constructing tests. Knowledge in constructing tests has a greater influence compared to self efficacy beliefs. The model match test results are obtained.

Table 1.Measurement Model Compatibility Test

\begin{tabular}{|c|c|c|c|c|}
\hline No. & Size Goodness Of Fit & Fit Criteria & Result & Information \\
\hline A & Absolute Fit Measures & & & \\
\hline 1 & Absolute Chi-Square (2) & $p>0.05$ & 17.57 & Good Fit \\
\hline 2 & $\begin{array}{l}\text { Goodness Of Fit Indices } \\
\text { (GFI) }\end{array}$ & $>0.9$ & 0.96 & Good Fit \\
\hline 3 & $\begin{array}{l}\text { Root Means Square Of } \\
\text { Approximation (RMSEA) }\end{array}$ & $<0.08$ & 0.018 & Good Fit \\
\hline 4 & $\begin{array}{c}\text { Standardized Root Mean } \\
\text { Square Residual (SRMR) }\end{array}$ & $<0.05$ & 0.042 & Good Fit \\
\hline 5 & $\begin{array}{l}\text { Expected Cross Validation } \\
\text { Index (ECVI) }\end{array}$ & $\begin{array}{l}<\text { ECVI saturated and } \\
\text { Independence model }\end{array}$ & $\begin{array}{c}0.56<0.73 \text { and } \\
0.56<4.3\end{array}$ & Good Fit \\
\hline $\mathrm{B}$ & Incremental Fit Measures & & & \\
\hline 1 & $\begin{array}{l}\text { Adjuted Goodness Of Fit } \\
\text { (AGFI) }\end{array}$ & $>0.9$ & 0.91 & Good Fit \\
\hline 2 & Normed Fit Index (NFI) & $>0.9$ & 0.96 & Good Fit \\
\hline 3 & Comparative Fit Index (CFI) & $>0.9$ & 1.00 & Good Fit \\
\hline
\end{tabular}




\begin{tabular}{|c|c|c|c|c|}
\hline 4 & Incremental Fit Index (IFI) & $>0.9$ & 1.00 & Good Fit \\
\hline 5 & Relative Fit Indices (RFI) & $>0.9$ & 0.93 & Good Fit \\
\hline $\mathrm{C}$ & Parsimonius Fit Measure & & & \\
\hline 1 & $\begin{array}{l}\text { Aiken's Information Criterion } \\
\text { (AIC) and Consistent Aikenke } \\
\text { Information Criterion (CAIC) }\end{array}$ & $\begin{array}{c}\text { AIC and CAIC default } \\
\text { model < AIC and } \\
\text { CAIC saturated and } \\
\text { independence model }\end{array}$ & $\begin{array}{c}55.57<72 \\
\text { and } 55.57< \\
426.8 \\
124.07<201.76 \\
\text { and } 124.07< \\
454.92\end{array}$ & Good Fit \\
\hline 2 & $\begin{array}{l}\text { Parsimonius Goodness Of Fit } \\
\text { Index (PGFI) }\end{array}$ & $>0.6$ & 0.45 & $\begin{array}{l}\text { Marginal } \\
\text { Fit }\end{array}$ \\
\hline
\end{tabular}

The results of testing the suitability of the measurement model indicate that 11 of the 12 sizes of the Goodness of Fit are declared good fit and 1 of the 12 sizes of the Goodness of Fit are declared marginal fit. In addition, each criterion of Goodness of Fit, namely absolute fit measurement, incremental fit measures, and parsimonius fit measures (measures of parsimony compatibility) is represented. Thus, the results of this test indicate that the suitability of the measurement model between the variables of the overall study is good.

Based on the results of testing using the Lisrel program, it is obtained that self efficacy belief has a positive direct effect on the quality of teachers in making mathematical cognitive test instruments. According to Bandura, self efficacy is defined as a person's belief that he can carry out a task at a certain level, influencing events that affect his life.[9]Self-efficacy belief is a key factor in the system of human abilities.[10]It can be considered as a theory that contains an individual's conscience related to how they motivate themselves, how they think, how they behave, and how they feel. It reflects the belief in the ability to teach a teacher himself.[11]Self-efficacy belief refers to people's assessment of their ability to regulate and influence actions that must be taken to achieve a predetermined goal.[10] It helps develop thinking about strategies, utilizes resources productively, and shows perseverance in facing difficulties. Not only does it affect goals and resilience in achieving goals, it also strives to achieve standard quality related to the performance obtained.[12]

The self-efficacy belief of teachers has a crucial influential role. It's power increases commitment to professionalism and collaborative relationships with peers and parents, contributing to the promotion for success and stimulated by the learning environment. These beliefs can affect job satisfaction directly by competency needs from within, indirectly derived from pride and gifts.[11]It can help teachers determine the expected results, because 
they have confidence in carrying out their duties and responsibilities to achieve success. Conversely, teachers who are skeptical of their abilities will be less stable in carrying out their duties and responsibilities. Teachers who have confidence, see difficult tasks as challenges to be mastered rather than as threats to avoid. They have stronger interest and deep preoccupation in carrying out their duties and responsibilities, arrange challenging goals, maintain strong commitment and enhance and support efforts in the face of failure. Teachers recover their beliefs faster after experiencing failure or setbacks.

Teachers who have high self-efficacy beliefs will try to arrange questions by paying attention to the rules in constructing the test. They will be able to overcome the difficulties in making these questions and will have commitment in carrying out the task of making cognitive test instruments. Also, they will think positively when assigned to make these instruments, considering that this task is the fulfillment of one of the competencies as a classroom teacher. Teachers who have high self-efficacy beliefs, have confidence, never give up, have higher targets, are oriented or committed to goals, develop ways to achieve goals, think positively, and are able to overcome work difficulties.[13]Teachers who have high selfefficacy include those who: see problem challenges as tasks that must be mastered, develop more attraction to activities that require participation, have a strong commitment to be interested in activities, recover quickly from setbacks and disappointments and have good health. Where as, people who have low self-efficacy: avoid challenges, believe that difficult tasks and situations are not within their abilities, focus on personal beliefs and failures, can end up in stress, depression, and lack vision of how to solve problems.[14]

Based on the results of testing using the Lisrel program, it is obtained that knowledge in constructing tests has a positive direct effect on the teachers in making mathematical cognitive test instruments. The results of testing this hypothesis indicate that the high and low knowledge construct the test. To be able to construct a test, knowledge about it is needed. A teacher who has this knowledge will possess knowledge about planning the preparation of test instruments, developing test items, analyzing test items, and assembling test instruments.

Tests made by the teacher must be good tests which have a positive and desirable effect on learning.[15]To be able to make a cognitive test instrument that is able to fulfill the validity and reliability criteria, definitely the teacher must have knowledge in constructing the test instrument. If a test is not planned in accordance with the procedure, it will certainly produce a test instrument that does not meet the criteria for validity and reliability. When the teacher does not even pay attention to the principles in developing the questions, the items will inevitably be made carelessly which results in these items being invalid.Constructing valid and reliable tests requires special knowledge and there exists literature on test construction.[16]In constructing the test, good agreement or expertise is required.[17]A teacher who lacks or doesn't even pay attention to how to plan tests, develop test items, and analyze test items will ultimately produce test instruments that do not meet the criteria of validity and reliability, and are not qualified.Constructing a valid test requires several steps that are carefully planned and implemented.[18] 


\section{Conclusion}

Based on the results of testing using the Lisrel program, it was obtained that self efficacy belief has a positive direct effect on the quality of teachers in making mathematical cognitive test instruments. This shows that variations in the quality variables of the quality of teachers in making these instruments are caused by self-efficacy beliefs, therefore changes in this variable will cause variations in the quality of teachers in making mathematical cognitive test instruments.Second, it was obtained that knowledge in constructing tests has a positive direct effect on the teachers in making mathematical cognitive test instruments. This means that variations in the teachers in making such instruments are caused by knowledge in constructing the test, so that changes in this variable will cause variations in the teachers in making these instruments.

\section{References}

[1] E. Dada and I. Ohia, "Teacher - Made Language Test Planning, Construction , Administration And Scoring In Secondary Schools In Ekiti State.," J. Educ. Pract., vol. 5, no. 18, pp. 71-76, 2014.

[2] \& O. Kinyua, "Validity and reliability of teacher - made tests: Case study of year 11 physics in Nyahururu District of Kenya," African Educ. Res. J., vol. 2, no. 2, pp. 61-71, 2014.

[3] N. Bray-clark and R. Bates, "Self-Efficacy Beliefs and Teacher Effectiveness : Implications for Professional Development," vol. XXVI, no. 1, pp. 13-22, 2003.

[4] R. S. Hamafyelto, A. Hamman-tukur, and S. S. Hamafyelto, "Assessing Teacher Competence in Test Construction and Content Validity of Teacher Made Examination Questions in Commerce in Borno State, Nigeria," vol. 5, no. 5, pp. 123-128, 2015.

[5] T. Tshabalala, T. Mapolisa, P. Gazimbe, and A. C. Ncube, "Establishing the Effectiveness of Teacher-Made Tests in Nkayi District Primary Schools," Nov. J. Humanit. Soc. Sci., vol. 4, no. 1 , pp. 1-6, 2015.

[6] L. M. Ing, M. B. Musah, S. H. V. Al-Hudawi, L. M. Tahir, and N. M. Kamil, "Validity of teacher-made assessment: A table of specification approach," Asian Soc. Sci., vol. 11, no. 5, pp. 193-200, 2015.

[7] A. Simsek, "A Comparative Analysis of Common Mistakes in Achievement Tests Prepared by School Teachers and Corporate Trainers," Eur. J. Sci. Math. Educ., vol. 4, no. 4, pp. 477-489, 2016.

[8] Fred C. Lunenburg, "Self-Efficacy in the Workplace: Implications for Motivation and Performance," Int. J. Manag. Business, Adm., vol. 14, no. 1, pp. 1-6, 2011. 
[9] “[Albert_Bandura]_Self-Efficacy_The_Exercise_of_Co(b-ok.org).pdf.".

[10] D. Pendergast, S. Garvis, and J. Keogh, "Pre-Service Student-Teacher Self-efficacy Beliefs: An Insight Into the Making of Teachers," Aust. J. Teach. Educ., vol. 36, no. 12, 2011.

[11] S. Sevgi and E. Education, "SELF-EFFICACY BELIEFS OF PROSPECTIVE TEACHERS *," vol. 7, no. 1, pp. 27-29, 2017.

[12] O. J. Olufemi, “Test Construction Techniques and Principles .,” no. September 2009, 2014.

[13] E. A. Locke and G. P. Latham, "Building a practically useful theory of goal setting and task motivation: A 35-year odyssey,” Am. Psychol., vol. 57, no. 9, pp. 705-717, 2002.

[14] J. Smith, B. Gardner, and S. Michie, "Self efficacy guidance material for Health Trainer Services," Cent. Outcomes Res. Eff., no. Centre for Outcomes Research and Effectiveness University College London, pp. 1-12, 2010.

[15] D. H. Lee, M. K. Kang, and Y. M. Kim, "A Study of validation on a modular-type for test construction in the college scholastic ability test," Int. J. Softw. Eng. its Appl., vol. 10, no. 12, pp. 131-138, 2016.

[16] P. Osadebe, "Construction of Valid and Reliable Test for Assessment of Students.," J. Educ. Pract., vol. 6, no. 1, pp. 51-57, 2015.

[17] A. Rahaman and V. F. Peter, "Construction of knowledge test on rules of hockey for physical education students," 2013.

[18] J. Rossiter, "How to construct a test of scienti c knowledge in consumer behavior," vol. 30, pp. 305-310, 2003. 